\section{Amphidiploid Induction from Diploid Rose Interspecific Hybrids}

\author{
Yan Ma ${ }^{1}$, David H. Byrne ${ }^{2}$, and Jing Chen ${ }^{3}$ \\ Department of Horticultural Sciences, Texas A\&MUniversity, College Station, \\ TX 77843-2133
}

Additional index words. Rosa, colchicine, chromosome doubling, breeding, polyploidy

\begin{abstract}
A high priority in rose (Rosa spp.) breeding research is the transfer of disease resistance, especially to black spot (Diplocarpon rosae Lib.), from wild diploid Rosa species to modern rose cultivars. To this end, amphidiploids $(2 n=4 x=28)$ were induced with colchicine from five interspecific diploid $(2 n=2 x=14)$ hybrids involving the black spot resistant diploid species $R$. wichuraiana Crép, $R$. roxburghii Thratt., $R$. banksiae Ait., $R$. rugosa rubra Hort., and $R$. setigera Michaux. Two application procedures (agitation of excised nodes in colchicine solution or tissue culture of shoots on medium with colchicine), five colchicine concentrations $(0.0,1.25,2.50,3.76$, and $5.01 \mathrm{mmol})$, and five durations $(2$, $3,5,8$, and $10 \mathrm{~d}$ ) were used. After colchicine treatment, the materials were cultured in vitro and the surviving explants were examined for the "gigas" characteristics typical of doubled diploids. Chromosome counts of morphologically suspect genotypes confirmed 15 amphidiploids among 1109 plants that survived colchicine treatment. Although the effect of colchicine treatment varied some among interspecific hybrids, $2.50 \mathrm{mmol}$ for $48 \mathrm{~h}$ of node agitation or $1.25 \mathrm{mmol}$ for at least $5 \mathrm{~d}$ of shoot culture were optimal.
\end{abstract}

Breeding roses for disease and pest resistance has lagged behind breeding for ornamental form. Few of the $\approx 200$ Rosa species have been evaluated for disease resistance or used for cultivar improvement. One reason is that most of the cultivars are tetraploid $(2 n=$ $4 x=28)$ or triploid $(2 n=3 x=21)$, while most of the wild species are diploid $(2 n=2 x=14)$ (Kriissmann, 1981). Triploid hybrids between diploid Rosa species and tetraploid cultivars are generally infertile and do not permit transfer of disease resistance from diploid species by backcrossing. In contrast to potato (Solanum tuberosum L.), nothing is known of $2 n$-gamete mechanisms in roses that would permit direct introduction of disease-resistance genes from diploids to tetraploids (Ortiz and Peloquin, 1991; Werner and Peloquin, 1991). Instead, the most promising transfer strategy is the production of comparatively fertile amphidiploids from diploid hybrids. Partially fertile hybrid roses have been obtained from crosses of amphidiploids with tetraploid cultivars (Basye, 1990, 1992).

Colchicine treatment is the classical method to induce doubling of chromosome number

\footnotetext{
Received for publication 4 Mar. 1996. Accepted for publication 12 Nov. 1996. We sincerely thank Charles F. Crane for critically reading the manuscript and providing useful comments. We also thank David M. Stelly and H. James Price for providing reagents and equipment for chromosome counts. The cost of publishing this paper was defrayed in part by the payment of page charges. Under postal regulations, this paper therefore must be hereby marked advertisement solely to indicate this fact.

'Postdoctoral Research Associate.

${ }^{2}$ Associate Professor.

${ }^{3}$ Laboratory Technician.
}

(Eigsti and Dustin, 1957). In roses, a few tetraploids have been induced from diploids by administering colchicine to shoot tips in vivo (Basye, 1990; Semeniuk and Arisumi, 1967,1968 ) or by incorporating it as a soak or into the media of in vitro systems (DrewesAlvarez, 1992; Roberts and Short, 1990). The success of the systems has been erratic. This study evaluates the effects of genotype, colchicine concentration, and two treatment protocols (media incorporation versus nodal soak) on the induction of amphidiploids from diploid interspecific rose hybrids using in vitro systems.

\section{Materials and Methods}

Five diploid interspecific hybrids were used: 89-1 ( $R$. wichuraiana Crép $\times R$. roxburghii Thratt.), 90-1 (R. wichuraiana $\mathrm{x}$. banksiae Ait.), 90-2 ( $R$. wichuraiana $\times R$. banksiae), 88-3 ( $R$. wichuraiana $\times R$. rugosa rubra Hort.), and 90-300 ( $R$. wichuraiana $\times$. setigera Michaux). These hybrids and their parents are maintained and used in the Texas A\&M Univ. rose breeding program.

The first of two experiments tested the effect of colchicine concentration on excised nodes that were subsequently regenerated. The second experiment factorially tested the effects of colchicine concentration and the duration of colchicine exposure on cultured shoot tips that were subsequently rooted. Both experiments included controls that were not exposed to colchicine, and were replicated with 16 to 90 explants per treatment.

For Expt. 1,264 single nodes were cut from greenhouse-grown, stock plants of 89-1, 90-1, and 90-2. The excised nodes were surface sterilized (Ma et al., 1996a), and then shaken orbitally at $90 \mathrm{rpm}$ in quarter-strength Murashige and Skoog (1962) salts solution (MS) with $0.00,1.25,2.50,3.76$, or $5.01 \mathrm{mmol}$ colchicine for $48 \mathrm{~h}$ in darkness at $25^{\circ} \mathrm{C}$. After this shake treatment, the nodes were transferred onto full-strength, solid MS medium with $3 \%$ sucrose, $0.7 \%$ agar, $8.9 \mathrm{mmol} \mathrm{6-}$ benzyladenine (BA), and $0.5 \mathrm{mmol}$ naphthalene acetic acid (NAA) and held for 2 weeks to initiate shoots, and then transplanted onto solid MS medium with $3 \%$ sucrose, $0.7 \%$ agar, and one-fourth the normal salt concentration and indoleacetic acid (IAA) at $0.6 \mathrm{mmol}$ for rooting. Culture conditions for shoot initiation and rooting were continuous cool-white fluorescent lighting $\left(90 \mu \mathrm{mol} \cdot \mathrm{m}^{-2} \cdot \mathrm{s}^{-1}\right)$ at $25^{\circ} \mathrm{C}$.

For Expt. 2, 1736 shoots $(\approx 1.5 \mathrm{~cm}$ long) were regenerated in vitro from stock plants of 89-1, 90-1, 90-2, 88-3, and 90-300. These shoots were directly transferred onto solid MS medium with $3 \%$ sucrose, $0.7 \%$ agar, half the normal salt concentration, and $0.00,1.25$, or $2.50 \mathrm{mmol}$ colchicine. The shoots were cultured in darkness at $10^{\circ} \mathrm{C}$ for $72,120,192$, or $240 \mathrm{~h}$, and then were transferred onto MS medium with one-fourth the normal salt concentration and $0.6 \mathrm{mmol}$ IAA for rooting at 25 ${ }^{\circ} \mathrm{C}$ under continuous cool-white fluorescent lighting $\left(90 \mu \mathrm{mol} \cdot \mathrm{m}^{-2} \cdot \mathrm{s}^{-1}\right)$.

In both experiments, shoot growth was visually rated near the end of a 2-week incubation period on the rooting medium. The rating scale was developed by sorting the plants over all genotypes into 10 homogeneous groups, where $1=$ almost dead, with yellow to brown leaves and shoots; $5=$ little or no growth, but green and healthy leaves and shoots; and 10= vigorous, leafy shoots. Shoot count, size, structure, and color affected the rating; thus, ratings were subjective because of the various trait combinations possible.

At the end of the 2-week incubation on the rooting medium, the roots were counted, and the explants were planted into a medium of 2 pine-bark mulch : 1 peat : 5 sand (by volume) and grown under ambient daylight and relative humidity in an unshaded greenhouse with a day/night cycle of $25^{\circ} \mathrm{C} / 22 \pm 5^{\circ} \mathrm{C}$. After 3 weeks, the survivors were counted, and for each survivor the length and width of both subterminal leaflets of the uppermost mature leaf were measured. The growth rating, number of roots, and percentage of explants that survived for the cultured-shoots (Expt. 2), were subjected to analyses of variance (ANOVA). Only the growth rating and percentage survival were used for ANOVA for the shaken nodes (Expt. 1). In both experiments, the treatment means were separated using Duncan's multiple range test (SAS Institute, 1988).

The survivors were visually assessed for characteristics typical of polyploidy in rose, i.e. thicker leaflets with a greater width: length ratio resulting in greater overlap among adjacent leaflets when compared to their diploid counterparts. The leaf tissue of induced tetraploid roses also tends to crinkle near the midrib. Shoot tips of 82 suspected tetraploids were pretreated, fixed, enzymatically digested, and stained in carbol-fuchsin for chromosome counts (Ma et al., 1996b). Because the frequency of chromosome doubling was so low, it was not included in the ANOVA. 


\section{Results and Discussion}

Experiment 1. Survival and growth of the shaken excised nodes was less in $90-1$ as compared to 89-1 and 90-2. In 89-1 and 90-1, the colchicine treatment decreased plant growth and survival as compared to the control (Table 1). The differences in growth of genotypes and the negative effect of colchicine on plant growth and survival are known (Drewes-Alvarez, 1992; Eigsti and Dustin, 1957; Ma et al., 1996a).

Chromosome counts of the putative tetraploids selected by leaf morphology identified nine tetraploids (Table 1). Five tetraploids were identified from 89-1 (Fig. 1), four from 90-1, and none from 90-2. Thus, the average frequency of induced amphidiploids was $4.2 \%$, with the best treatments giving $8 \%$ to $13 \%$ induction. The most consistently effective colchicine concentration was $2.50 \mathrm{mmol}$. This concentration compares favorably to induction rates ( $2 \%$ to $14 \%$ depending on the genotype and treatment) reported with another in vitro system (Drewes-Alvarez, 1992).

Experiment 2. As with the previous experiment, plant growth, root production, and survival were affected by the colchicine treatment and the genotype used. In general, as the concentration and duration of the colchicine exposure increased, there was a decrease in plant growth, root production, and survival (Table 2). Without colchicine, shoot growth was best in 89-1 and least in 90-1, root production was best in 90-300 and least in 89-1, and survival was between $83 \%$ to $90 \%$ for all genotypes. The growth differences were consistent over colchicine treatments, although survival decreased less with increasing colchicine exposure in 90-300 than for the other four genotypes.

Only six amphidiploids were identified in this experiment (Table 2). Both approaches failed to produce an amphidiploid of 90-2. Thus, the overall induction rate was $0.4 \%$, with the best treatments producing $2 \%$ to $3 \%$ tetraploids, which is lower than the shaken- nodes approach and lower than that reported previously for in vitro systems (DrewesAlvarez, 1992). The lowest nonzero colchicine concentration $(1.25 \mathrm{mmol})$ was more effective than $2.50 \mathrm{mmol}$.

With both treatments, the most effective colchicine level was the lowest nonzero level [2.50 mmol with the shake method (Expt. 1) and $1.25 \mathrm{mmol}$ with media incorporation (Expt. 2)]. Higher concentrations of colchicine did not induce more tetraploid plants, probably because of colchicine's toxicity to plants or inhibition of cell division. If the dose of colchicine required to depolymerize rose microtubules is only slightly less than the lethal dose, then exposure to excessive colchicine might kill all the just-induced tetraploid cells. An alternate, and possibly related, explanation is colchicine's inhibition of cell division in rose (Roberts et al., 1990) at the concentrations used in this study ( 1.25 to $2.50 \mathrm{mmol}$ ). Since colchicine doubles chromosome numbers only of dividing cells whose microtubules are depolymerized by it, a lower frequency of tetra-

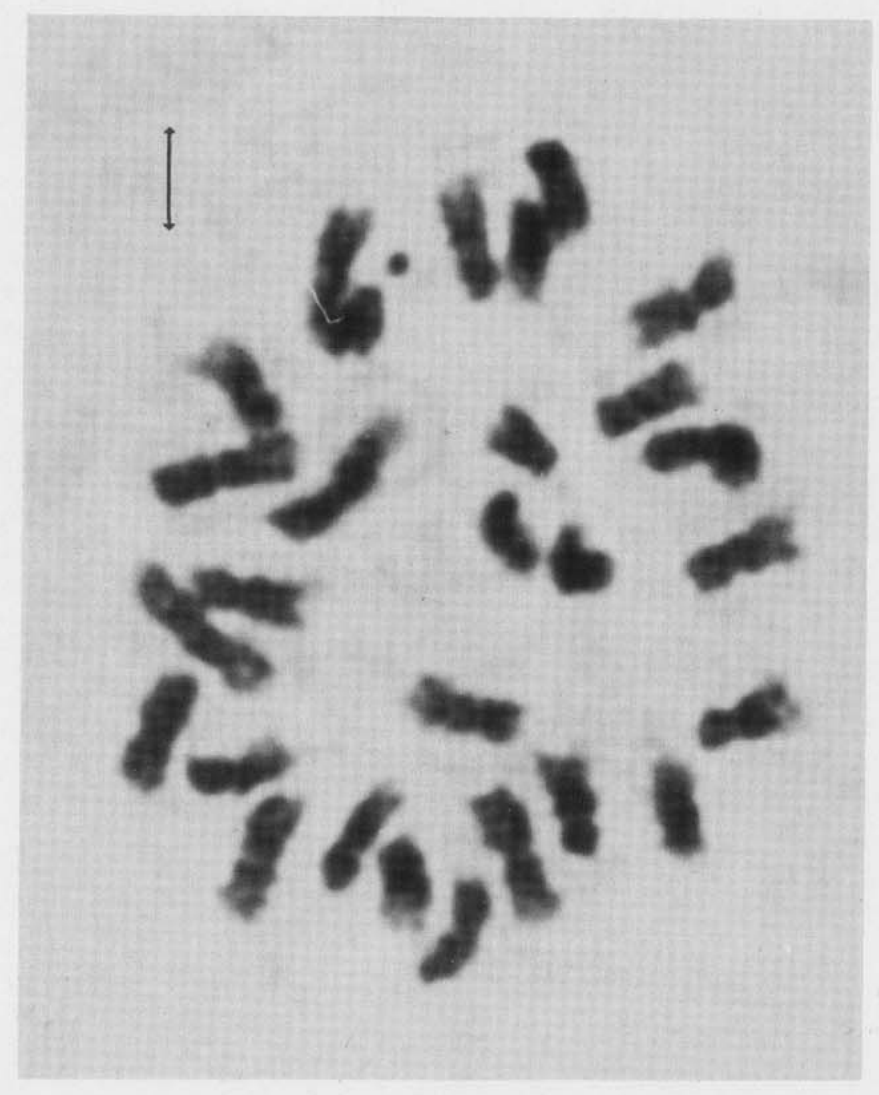

Fig. 1. Chromosomes of an amphidiploid $(2 n=4 x=28)$ induced from genotype $89-1$; bar $=2.5 \mathrm{~mm}$ Table 1. Effect of colchicine treatment of shaken excised nodes on the induction of amphidiploidy from interspecific diploid rose hybrids.

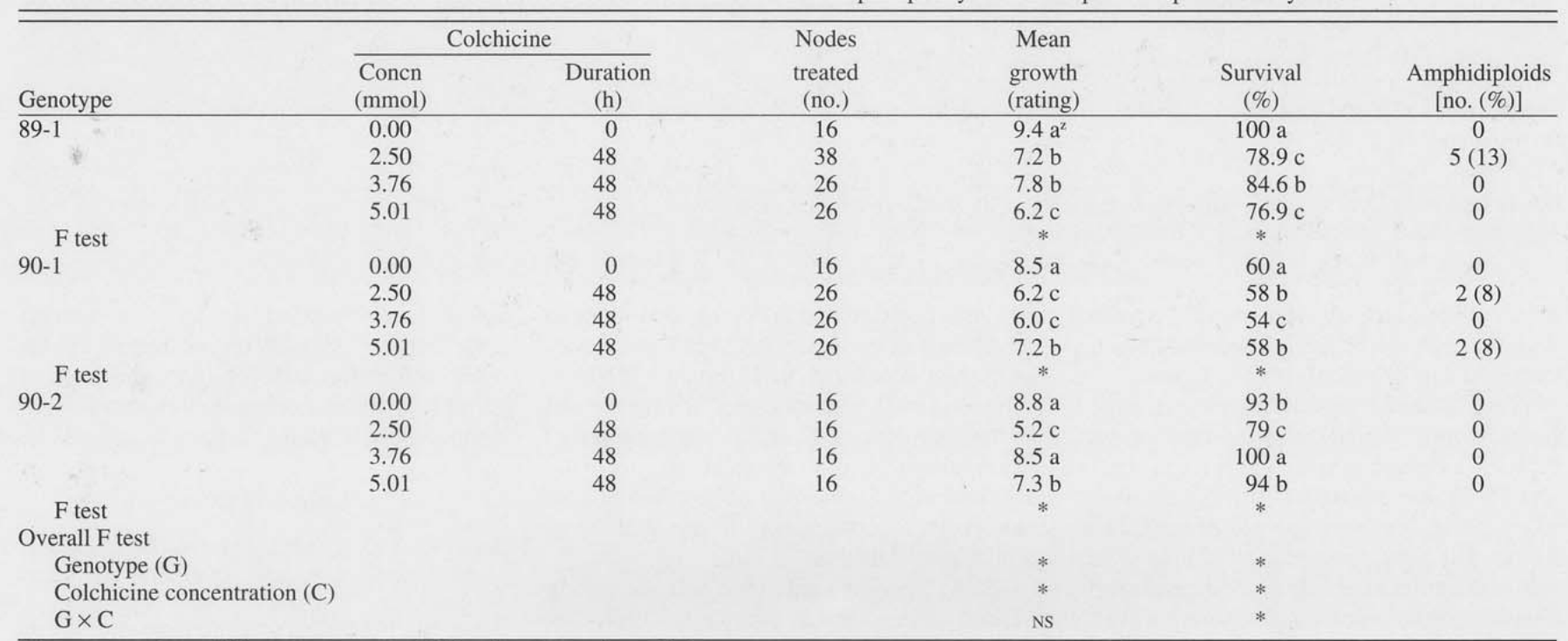

${ }^{2}$ Mean separations within columns at $P \leq 0.05$ using Duncan's multiple range test.

Ns, "Nonsignificant or significant at $P \leq 0.05$, respectively. 
Breeding, Cultivars, Rootstocks, and Germplasm Resources

Table 2. Effect of colchicine treatment of cultured shoot tips on the induction of amphidiploidy from interspecific diploid rose hybrids.

\begin{tabular}{|c|c|c|c|c|c|c|c|}
\hline \multirow[b]{2}{*}{ Genotype } & \multicolumn{2}{|c|}{ Colchicine } & \multirow{2}{*}{$\begin{array}{l}\text { Explants } \\
\text { treated } \\
\text { (no.) }\end{array}$} & \multirow{2}{*}{$\begin{array}{l}\text { Mean } \\
\text { growth } \\
\text { (rating) }\end{array}$} & \multirow{2}{*}{$\begin{array}{l}\text { Roots } \\
\text { per } \\
\text { explant }\end{array}$} & \multirow[b]{2}{*}{$\begin{array}{c}\text { Survival } \\
(\%)\end{array}$} & \multirow[b]{2}{*}{$\begin{array}{c}\text { Amphidiploids } \\
\text { [no. }(\%)]\end{array}$} \\
\hline & $\begin{array}{l}\text { Concn } \\
(\mathrm{mmol})\end{array}$ & $\begin{array}{l}\text { Duration } \\
\text { (h) }\end{array}$ & & & & & \\
\hline \multirow[t]{9}{*}{$89-1$} & 0.00 & 0 & 46 & $9.6 \mathrm{a}^{z}$ & $5.6 \mathrm{a}$ & $87 \mathrm{a}$ & 0.0 \\
\hline & 1.25 & 72 & 52 & $8.6 \mathrm{~b}$ & $3.2 \mathrm{c}$ & $83 \mathrm{~b}$ & 0.0 \\
\hline & 1.25 & 120 & 47 & $6.8 \mathrm{f}$ & $2.7 \mathrm{e}$ & $75 \mathrm{c}$ & $1(2)$ \\
\hline & 1.25 & 192 & 46 & $7.2 \mathrm{~d}$ & $2.8 \mathrm{e}$ & $70 \mathrm{~d}$ & $1(2)$ \\
\hline & 1.25 & 240 & 90 & $6.7 \mathrm{fg}$ & $2.5 \mathrm{e}$ & $51 \mathrm{f}$ & 0.0 \\
\hline & 2.50 & 72 & 48 & $7.6 c$ & $3.8 \mathrm{~b}$ & $77 \mathrm{c}$ & 0.0 \\
\hline & 2.50 & 120 & 45 & $7.1 \mathrm{e}$ & $3.0 \mathrm{~d}$ & $58 \mathrm{e}$ & 0.0 \\
\hline & 2.50 & 192 & 52 & $7.0 \mathrm{ef}$ & $1.8 \mathrm{f}$ & $52 \mathrm{f}$ & 0.0 \\
\hline & 2.50 & 240 & 69 & $6.6 \mathrm{~g}$ & $1.2 \mathrm{~g}$ & $38 \mathrm{~g}$ & 0.0 \\
\hline F test & & & & $*$ & $*$ & $*$ & \\
\hline \multirow[t]{9}{*}{$90-1$} & 0.00 & 0 & 46 & $6.4 \mathrm{a}$ & $7.9 \mathrm{a}$ & $85 \mathrm{a}$ & 0.0 \\
\hline & 1.25 & 72 & 26 & $6.4 \mathrm{a}$ & $7.7 \mathrm{~b}$ & $62 c$ & 0.0 \\
\hline & 1.25 & 120 & 22 & $5.9 \mathrm{~b}$ & $7.4 \mathrm{~b}$ & $50 \mathrm{c}$ & 0.0 \\
\hline & 1.25 & 192 & 42 & $5.6 \mathrm{c}$ & $4.4 \mathrm{c}$ & $43 \mathrm{e}$ & 0.0 \\
\hline & 1.25 & 240 & 41 & $5.2 \mathrm{~d}$ & $2.7 \mathrm{~d}$ & $37 \mathrm{f}$ & $1(2)$ \\
\hline & 2.50 & 72 & 25 & $5.1 \mathrm{~d}$ & $8.2 \mathrm{a}$ & $60 \mathrm{c}$ & 0.0 \\
\hline & 2.50 & 120 & 20 & $5.0 \mathrm{ef}$ & $5.2 \mathrm{c}$ & $45 \mathrm{~d}$ & 0.0 \\
\hline & 2.50 & 192 & 20 & $4.9 \mathrm{f}$ & $5.4 \mathrm{c}$ & $40 \mathrm{~d}$ & 0.0 \\
\hline & 2.50 & 240 & 45 & $4.9 \mathrm{f}$ & $2.4 \mathrm{~d}$ & $39 \mathrm{f}$ & 0.0 \\
\hline $\mathrm{F}$ test & & & & $*$ & * & $*$ & \\
\hline \multirow[t]{9}{*}{$90-2$} & 0.00 & 0 & 46 & $8.5 \mathrm{a}$ & $6.3 \mathrm{a}$ & $83 \mathrm{a}$ & 0.0 \\
\hline & 1.25 & 72 & 22 & $7.2 \mathrm{c}$ & $5.9 \mathrm{~b}$ & $61 \mathrm{~b}$ & 0.0 \\
\hline & 1.25 & 120 & 22 & $7.5 \mathrm{~b}$ & $3.8 \mathrm{~b}$ & $50 \mathrm{~d}$ & 0.0 \\
\hline & 1.25 & 192 & 42 & $6.3 \mathrm{~d}$ & $2.6 \mathrm{c}$ & $43 \mathrm{ef}$ & 0.0 \\
\hline & 1.25 & 240 & 21 & $5.0 \mathrm{~g}$ & $1.3 \mathrm{e}$ & $33 \mathrm{~g}$ & 0.0 \\
\hline & 2.50 & 72 & 24 & $5.8 \mathrm{e}$ & $2.7 \mathrm{c}$ & $54 \mathrm{c}$ & 0.0 \\
\hline & 2.50 & 120 & 19 & $5.0 \mathrm{~g}$ & $2.2 \mathrm{~cd}$ & $42 \mathrm{e}$ & 0.0 \\
\hline & 2.50 & 192 & 27 & $5.4 \mathrm{f}$ & $2.0 \mathrm{de}$ & $44 \mathrm{e}$ & 0.0 \\
\hline & 2.50 & 240 & 42 & $4.8 \mathrm{~h}$ & $1.9 \mathrm{de}$ & $38 \mathrm{f}$ & 0.0 \\
\hline $\mathrm{F}$ test & & & & $*$ & $*$ & $*$ & \\
\hline \multirow[t]{9}{*}{$88-3$} & 0.00 & 0 & 20 & $8.2 \mathrm{c}$ & $7.8 \mathrm{a}$ & $90 \mathrm{a}$ & 0.0 \\
\hline & 1.25 & 72 & 41 & $6.8 \mathrm{c}$ & $6.3 \mathrm{~b}$ & $60 \mathrm{~b}$ & 0.0 \\
\hline & 1.25 & 120 & 45 & $6.2 \mathrm{~d}$ & $4.6 \mathrm{c}$ & $56 \mathrm{c}$ & 0.0 \\
\hline & 1.25 & 192 & 40 & $7.6 \mathrm{~b}$ & $4.5 \mathrm{c}$ & $48 \mathrm{e}$ & $1(3)$ \\
\hline & 1.25 & 240 & 37 & $5.0 \mathrm{~g}$ & $3.4 \mathrm{~d}$ & $49 \mathrm{e}$ & 0.0 \\
\hline & 2.50 & 72 & 39 & $6.7 \mathrm{c}$ & $6.7 \mathrm{~b}$ & $51 \mathrm{~d}$ & 0.0 \\
\hline & 2.50 & 120 & 35 & $5.7 \mathrm{e}$ & $3.3 \mathrm{~d}$ & $31 \mathrm{~g}$ & 0.0 \\
\hline & 2.50 & 192 & 50 & $5.2 \mathrm{f}$ & $3.4 \mathrm{~d}$ & $34 \mathrm{f}$ & 0.0 \\
\hline & 2.50 & 240 & 38 & $4.2 \mathrm{~h}$ & $3.2 \mathrm{~d}$ & $32 \mathrm{~g}$ & 0.0 \\
\hline F test & & & & $*$ & $*$ & $*$ & \\
\hline \multirow[t]{9}{*}{$90-300$} & 0.00 & 0 & 20 & $8.9 \mathrm{a}$ & $13.1 \mathrm{a}$ & $90 \mathrm{a}$ & 0.0 \\
\hline & 1.25 & 72 & 39 & $6.4 \mathrm{~d}$ & $12.7 \mathrm{~b}$ & $71 \mathrm{~b}$ & 0.0 \\
\hline & 1.25 & 120 & 23 & $5.2 \mathrm{~g}$ & $12.1 \mathrm{~b}$ & $70 \mathrm{~b}$ & 0.0 \\
\hline & 1.25 & 192 & 25 & $5.4 \mathrm{f}$ & $8.6 \mathrm{~cd}$ & $58 \mathrm{bc}$ & 0.0 \\
\hline & 1.25 & 240 & 68 & $4.3 \mathrm{~h}$ & $8.4 \mathrm{~cd}$ & $32 \mathrm{~d}$ & $2(3)$ \\
\hline & 2.50 & 72 & 58 & $8.2 \mathrm{~b}$ & $9.0 \mathrm{~cd}$ & $72 b$ & 0.0 \\
\hline & 2.50 & 120 & 24 & $5.8 \mathrm{e}$ & $8.1 \mathrm{e}$ & $58 \mathrm{bc}$ & 0.0 \\
\hline & 2.50 & 192 & 29 & $7.4 \mathrm{c}$ & $9.3 \mathrm{c}$ & $59 \mathrm{bc}$ & 0.0 \\
\hline & 2.50 & 240 & 58 & $4.4 \mathrm{~h}$ & $8.2 \mathrm{de}$ & $57 c$ & 0.0 \\
\hline $\mathrm{F}$ test & & & & $*$ & $*$ & $*$ & \\
\hline \multicolumn{8}{|c|}{ Overall F test } \\
\hline \multicolumn{4}{|c|}{ Genotype (G) } & * & * & * & \\
\hline \multicolumn{3}{|c|}{ Colchicine concentration (C) } & & * & * & * & \\
\hline \multicolumn{2}{|c|}{ Duration } & & & * & * & * & \\
\hline $\mathrm{G} \times \mathrm{C}$ & & & & NS & NS & * & \\
\hline
\end{tabular}

${ }^{2}$ Mean separation within columns different at $P \leq 0.05$, using Duncan's multiple range test.

Ns, "Nonsignificant or significant at $P \leq 0.05$, respectively.

ploid cells might result in the meristems treated with the higher colchicine concentrations because the rate of cell division is lower.

The induced tetraploids tended to have a higher width : length ratio than the original diploids although in some cases (e.g., 90-300 and 88-3), the difference in proportions between ploidy levels was nonsignificant (Table 3). Nevertheless, these tetraploid plants were visually distinguishable from the diploid plants. One unexpected result was the variation among colchicine-induced tetraploids obtained from the same diploid hybrid. Although mixoploidy has been detected in other colchicine-induced tetraploids in the Texas A\&M collection (unpublished data) and in Germany (DrewesAlvarez, 1992), none was detected in the counts of these genotypes. Thus, this variation possibly resulted from differences in maturity of the leaves sampled, environmental differences in the growing conditions of the plants, or somaclonal variation.

Rose breeding demands a balance among several desired traits, especially color, fragrance, floral form, and disease resistance. The 15 amphidiploids identified carry the high levels of resistance to black spot from several diploid species, but will require several cycles of recombination with commercial tetraploid germplasm to incorporate their resistance into a commercially useful form.

\section{Literature Cited}

Basye, R. 1990. An amphidiploid of Rosa banksiae and Rosa laevigata induced by colchicine. Amer. Rose Ann. 75:82-88.

Basye, R. 1992. The future of the rose. 1992. Amer. Rose Ann. 77:60-63.

Drewes-Alvarez, R. 1992. Untersuchungen am 
Table 3. Ratio of rose leaflet width : length of amphidiploids compared to their original interspecific diploid.

\begin{tabular}{|c|c|c|c|}
\hline Genotype & Test sample & Width : length & $\operatorname{LSD}_{0.01}$ \\
\hline \multirow[t]{9}{*}{$89-1$} & Control $^{2}$ & 0.56 & 0.044 \\
\hline & $\mathrm{A}^{\mathrm{y}}$ & 0.71 & $* *$ \\
\hline & B & 0.70 & $* *$ \\
\hline & $\mathrm{C}$ & 0.73 & $* *$ \\
\hline & D & 0.72 & $* *$ \\
\hline & E & 0.77 & $* *$ \\
\hline & $\mathrm{F}$ & 0.64 & $* *$ \\
\hline & G & 0.83 & $* *$ \\
\hline & H & 0.78 & $* *$ \\
\hline \multirow[t]{6}{*}{$90-1$} & Control & 0.61 & 0.092 \\
\hline & A & 0.73 & $* *$ \\
\hline & B & 0.79 & $* *$ \\
\hline & $\mathrm{C}$ & 0.67 & NS \\
\hline & D & 0.79 & $* *$ \\
\hline & $\mathrm{E}$ & 0.71 & $* *$ \\
\hline \multirow[t]{2}{*}{$88-3$} & Control & 0.62 & 0.151 \\
\hline & A & 0.69 & NS \\
\hline \multirow[t]{3}{*}{$90-300$} & Control & 0.68 & 0.093 \\
\hline & A & 0.73 & NS \\
\hline & B & 0.74 & NS \\
\hline
\end{tabular}

${ }^{2}$ Control $=$ the original interspecific diploid rose hybrid.

${ }^{y} \mathrm{~A}-\mathrm{H}=$ amphidiploids from the same interspecific diploid rose hybrid.

Ns, ${ }^{* *}$ Nonsignificant or significantly different from the control at $P<0.01$.

Pathosystem Sternrusstau (Marssonina rosae $<$ Lib. $>$ Died.) - Rose (Rosa L.) zur Klaerung der Frage nach pilzlichen Rassen und zur Uebertragung der Resistenz aus der diploiden Rosa multiflora Thunb. auf tetraploide Garten- rosen. PhD Diss., Univ. of Hamburg, Germany.

Eigsti O.J. and P. Dustin, Jr. 1957. Colchicine-In agriculture, medicine, biology, and chemistry. The Iowa State College Press, Ames.
Griesbach,R.J. 1990. A fertile tetraploid Anigozanthos hybrid produced by in vitro colchicine treatment. HortScience 25:802-803.

Krüssmann, G. 1981. The complete book of roses. Timber Press. Portland, Ore.

Ma, Y., D.H. Byrne, and J. Chen. 1996a. Propagation of rose species in vitro. In Vitro Cell. Devel. Biol. Plant 32:103-108.

Ma, Y., M.N. Islam-Faridi, C.F. Crane, D.M. Stelly, H.J. Price, and D.H. Byrne. 1996b. A new procedure for making metaphase chromosome slides in roses. HortScience 31:855-857.

Murashige, T. and F. Skoog. 1962. A revised medium for rapid growth and bioassays with tobacco cultures. Physiol. Plant 15:473-497.

Ortiz, R. and S.J. Peloquin. 1991. A new method of producing $4 \mathrm{x}$ hybrid true potato seed. Euphytica 57:103-107.

Roberts, A.V., D. Lloyd, and K.C. Short. 1990. Procedures for the induction of tetraploidy in a diploid rose. Euphytica 49:33-38.

Semeniuk, P. and T. Arisumi. 1967. A method of inducing polyploidy in roses. Amer. Rose Ann. 52:148-149.

Semeniuk, P. and T. Arisumi. 1968. Colchicineinduced tetraploid and cytochimeral roses. Bot. Gaz. 129:190-193.

SAS Institute, Inc. 1988. SAS/STAT user's guide, release 6.03 ed. SAS Inst., Cary, N.C.

Werner, J. and S.J. Peloquin. 1991. Yield and tuber characteristics of $4 \mathrm{x}$ progeny from $2 \mathrm{x} \times 2 \mathrm{x}$ crosses. Potato Res. 34:261-267. 